\title{
CO2 Emission Due To Excavation
}

\author{
Prashant, Kongan Aryan, A.K Gupta
}

\begin{abstract}
Rapid urbanization in developing countries causes the emission of greenhouse gases. A major part of emission is released by infrastructure construction sites. construction process involves excavation, (which is a significant area of study, given that it involves changing the site by disturbing and removing vegetation. The main gases which are associated with excavation include carbon dioxide(CO2), methane $(\mathrm{CH} 4)$ and nitrous oxide( $\mathrm{N2O}$ ). These gases (greenhouse gases) are responsible for global warming. Nearly about $22.6 \%$ emission of co2 is due to earthwork on the construction site. Although excavation is economical in terms of delivering a flat base for raft construction, the environmental outcome of this approach needs to be examined more carefully in terms of influencing the environment. The air quality in India according to a WHO one of the polluted country in the world. In this situation, controlling and reducing pollution is an area of prime concern.
\end{abstract}

\section{INTRODUCTION}

Since the industrial revolution, humans are simultaneously started converting natural ecosystems into industrial and agricultural land for satisfying human needs which results in the depletion of soil organic matter levels, releasing 100GT of carbon from soil into the environment.

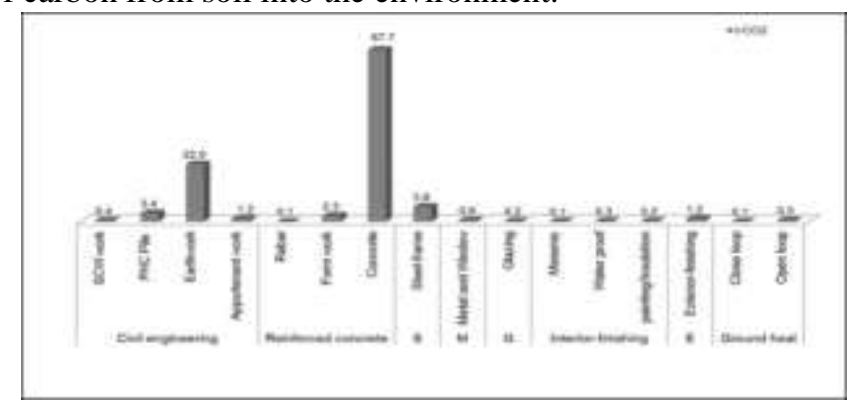

The development of infrastructures in the past decade has consequence depletion of a considerable amount of soil carbon stocks. The soil is the largest pool of carbon and has potential to holds expanded carbon sequestration, and provide a potential way of minimizing the increased carbon dioxide concentration in the atmosphere. Globally construction is an important sector that contributes greatly to the social and economic growth. The major impacts of construction are excessive energy, natural resources usage, and climate change. Earthwork in a construction process is considered one of the major processes which involve emission of $\mathrm{Co} 2$ in the atmosphere. Excavation of soil for the construction of the sub-structure of a building is an important process. It is remarkable that some processes of construction impact the ground more heavily than others, for example, cut and fill excavation which is used in sloping sites. In the process of excavation, the soil is disturbed and manipulated therefore the pores carrying gases are exposed in the atmosphere and the trapped gases are released in the atmosphere.

\begin{tabular}{|l|c|c|}
\hline \multirow{2}{*}{ Name of gas } & \multicolumn{2}{|c|}{ Percentage by volume } \\
\cline { 2 - 3 } & Soil air & Abmospheric air \\
\hline Oxygen & 20.00 & 21.00 \\
Ningen & 78.60 & 78.03 \\
Carbondiaxide & 0.50 & 0.03 \\
Argan & 0.90 & 0.94 \\
\hline
\end{tabular}

Soil respiration has two main components: heterotrophic respiration (Soil organic matter is composed of soil fauna which includes bacteria and fungi and products formed from their decomposition) and autotrophic or root respiration. There are pores in the soil structure which carry nitrogen, carbon dioxide, and oxygen. The percentage of carbon in the soil is $0.25 \%$ and 0.04 in the atmosphere. Soil air contains a much greater proportion of carbon dioxide than the atmospheric air.

\section{CO2 FIXATION IN SOIL AS SOIL ORGANIC CARBON}

Carbon is Carbon dioxide (Co2) is much more abundant in soil gas (the air in soil) than in the atmosphere. That's because plant roots respire and produce $\mathrm{Co} 2$. Oxidation of organic matter by fauna present in soil releases co2 as their by-products. In the presence of sunlight, carbon dioxide and water plants create the simple sugar glucose which is made up of carbon, oxygen, and hydrogen in those starting materials. This process is known as photosynthesis. The walls of each plant cell contain fibers made of differing amounts of carbon, hydrogen, and oxygen. When a plant dies, microbes and even larger fungi break down these fibers. The decomposer organism can use that sugar for growth, reproduction and other activities
Revised Version Manuscript Received on August 19, 2019.

Prashant, Student, Civil Engineering, Delhi Technological University, India.

Kongan Aryan, Department of Civil and Environmental Engineering,

Delhi Technical University, Delhi, India (e-mail: akgupta@dce.ac.in).

A.K Gupta, Department of Civil Engineering, Delhi Technical University, Delhi, India. 


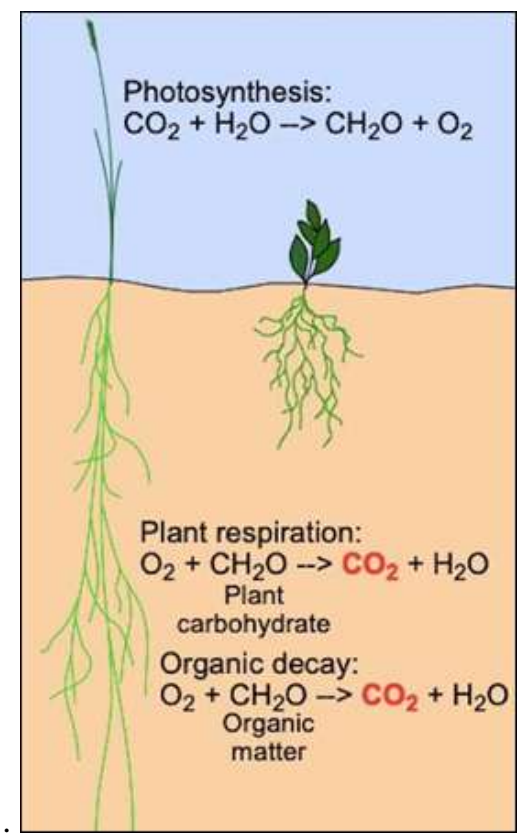

Along the way, it releases carbon dioxide back into the soil and rests it fix carbon as soil organic carbon. Soil organic matter contains bacteria and fungi, decaying material like fecal material, plants and products formed by their decomposition. SOM is made of organic compounds that are highly enriched in carbon. Soil organic carbon (SOC) levels are directly related to the amount of organic matter contained in soil and SOC is often how organic matter is measured in soils. More the amount of SOC more will be the number of deomposers and more will be the $\operatorname{co} 2$ present in soil.

\section{MEASUREMENT AND METHODOLOGY SAMPLING}

Ideally, soil samples undergoing analysis are the area of interest. There must be multiple numbers of samples so that we can estimate variance. So we take 4 soil samples per field. Initially, we take the first sample in the middle of the field and rest are taken 90 degrees apart from each other with respect to the first point taken. We should avoid hard soil because it is harder to dig the soil.

Before taking the samples the litters are removed one by one with hands. Soil samples are taken at different depths(i.e. $0-10 \mathrm{~cm}, 10-30 \mathrm{~cm}, 30-100 \mathrm{~cm}$ etc.). By this process, we can determine both carbon(organic carbon) abundance and soil bulk density at different depths of the soil.

precisely determination of the SBD (soil bulk density) in the uppermost layers of the soil is important because in shallow location SBD (soil bulk density) show maximum variation. A large amount of soil organic carbon is present in the shallow depth of soil. soil sampling at a depth of $30-50 \mathrm{~cm}$ is difficult due to hardness at that depth and it requires more time and effort.

\section{SAMPLE PREPARATION}

Samples are taken to the laboratory where the samples are weighed and kept in their respective air sealed bags, clumps of the soil are broken down by hands and then dried at $40^{\circ} \mathrm{C}$. Afterward, a small sample of each soil sample is heated at $105^{\circ} \mathrm{C}$ in an oven for 4 hours so we can calculate and find out the bulk density of that sample. And the remaining samples are drily sieved and measure the gravel and root content present in the sample by weight.

\section{QUANTIFICATION OF SOIL ORGANIC CARBON STOCK}

There are various ways to calculate soil carbon stock and all of them provide the measurement of SOC(soil organic carbon) per unit area. The method we are using is spital coordinator method which helps us to calculate the stocks of carbon present in the given soil sample by taking reference of the depth and area.

With this procedure, we can calculate the soil carbon stock for given depths.

$\mu \mathrm{d}=$ organic carbon stock BDD $=\mathrm{BD}$ (bulk density)

$\mathrm{OCD}=$ the concentration of organic carbon $\mathrm{D}=$ soil sample depth

gr. $=$ FGC(fractional gravel content $)$

\section{SCALING SOIL ORGANIC CARBON TO THE WHOLE LAND}

The average Soil organic carbon stock for a given sample is calculated

$$
\mu_{\mathrm{st}}=\frac{1}{n} \sum_{i=1}^{n} y_{i}
$$

here:-

$\mu \mathrm{st}=$ mean soil organic carbon stock for stratum $y i=c a l c u l a t e d$ Soil organic carbon stock in that stratum $\mathrm{n}=$ number of readings in that stratum

The average soil organic carbon for a given area is calculated by considering both:-

1) area occupied by stratum

2) mean SOC stock

here:-

$\mu=$ mean soil organic carbon stock $\mathrm{ah}=$ area (stratum)

$\mu \mathrm{h}=$ mean Soil organic carbon stock correlated with the stratum $h$

$\mathrm{A}=$ total area

\section{RESULT}

We performed these tests on different types of soils like Alfisols, Entisols, and Inceptisols at different depths. We found out that in the topsoil $(0-30 \mathrm{~cm})$ the soil organic carbon and its density is maximum. Using the $100 \mathrm{~cm}$ reference

$47 \%(684-724 \mathrm{pgC})$ of soil organic carbon is in upper $30 \mathrm{~cm}$ and $53 \%(778-824 \mathrm{PgC})$ in the layer of $30-100 \mathrm{~cm}$.

\begin{tabular}{|c|c|c|c|c|c|}
\hline \multirow{3}{*}{$\begin{array}{c}\text { C- } \\
\text { Type }\end{array}$} & \multicolumn{5}{|c|}{ Depth Layer } \\
\hline & $0-30$ & $\begin{array}{l}30- \\
100\end{array}$ & $\begin{array}{l}100- \\
200\end{array}$ & $\begin{array}{l}200- \\
300\end{array}$ & $0-100$ \\
\hline & $\mathrm{cm}$ & $\mathrm{cm}$ & $\mathrm{cm}$ & $\mathrm{cm}$ & $\mathrm{cm}$ \\
\hline $\mathrm{SC}$ & & & & & $\begin{array}{l}2157 \\
2293\end{array}$ \\
\hline soc & $\begin{array}{l}684- \\
724\end{array}$ & $\begin{array}{l}778- \\
824\end{array}$ & $\begin{array}{l}914- \\
908\end{array}$ & & $\begin{array}{c}1462 \\
1548\end{array}$ \\
\hline
\end{tabular}


In the uppermost layer, organic material is concentrated and carbon mineralization is more active. The vertical distribution of soil organic carbon generally decreases with depth.

Decreasing I s non-linear when we plot it into the graph as shown.
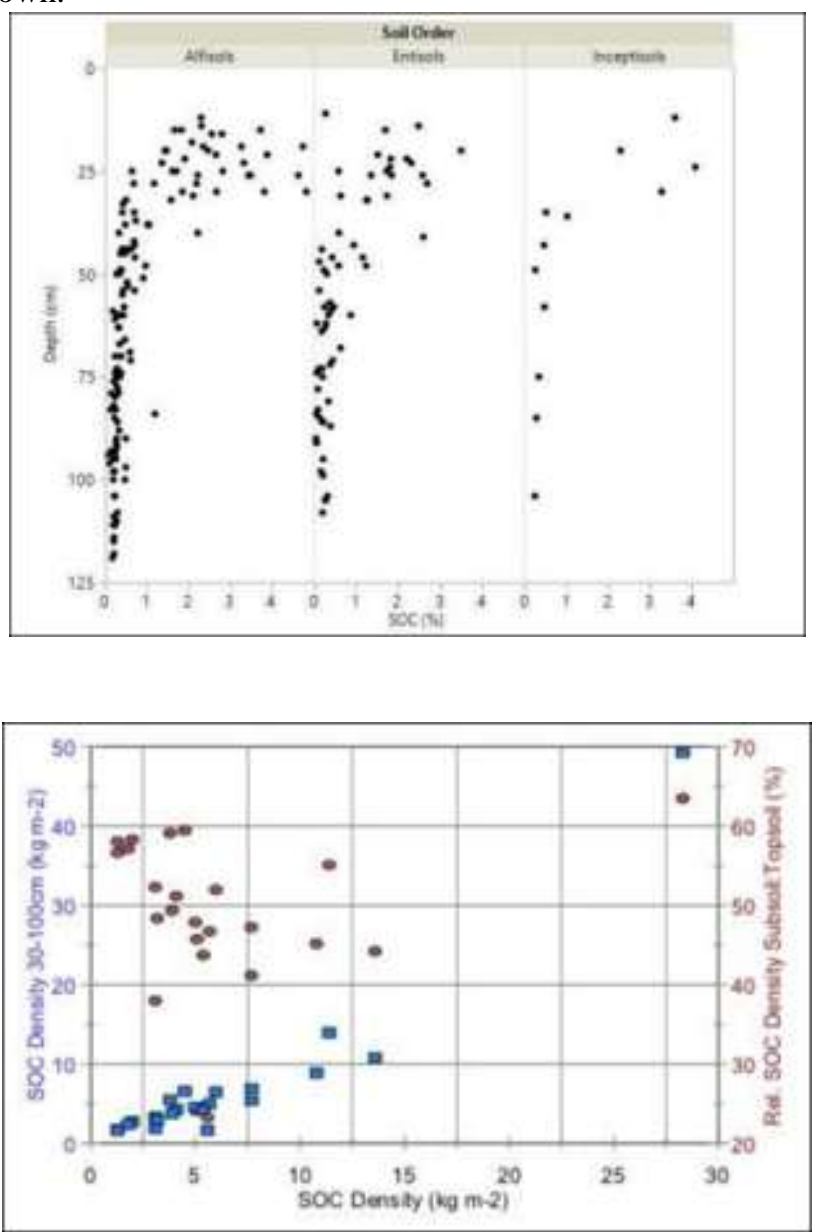

As the results show the topsoil contains the maximum amount of soil organic matter. decomposition of these organic matter produces carbon dioxide. Hence, soil rich in organic matter contains a higher percentage of $\mathrm{Co} 2$. If vegetation is present the $\mathrm{co} 2$ concentration is higher then fallow lands. The concentration is higher near the root tips because of respiration by roots. temperature also impacts on the concentration of $\mathrm{CO} 2$. high temperature cause more microbial activity so results in higher production of $\mathrm{CO} 2$.

\section{CONCLUSION}

Soil organic carbon is one of the most important components of soil which helps our ecosystem to function properly. It is useful among the zestful ecological processes like photosynthesis, soil respiration, and decomposition. Human activities are the reasons for the depletion of soil organic carbon stock and resulting in climate change. More the amount of organic matter present in the soil more will be the concentration of $\mathrm{CO} 2$ present in the soil.

In constructing a structure excavation plays an important role in making foundations of home, roadways, and building. In this process, the soil is being dug to a certain depth. A huge amount of soil is extracted from the ground and if the soil organic amount is more in the soil then there is a great possibility that there must be huge of co2 trapped into the soil.

The excavated soil gets disturbed by the heavy machinery and the $\mathrm{CO} 2$ which is trapped in the soil gets in contact with the atmosphere. due to which co2 released in the environment which is a greenhouse gas responsible for global warming and climate change.

\section{REFERENCES}

1. Batjes, N.H. (2002) A homogenized soil profile data set for global and regional environmental research (WISE, V 1.1). International Soil Reference and Information Centre, Wageningen, The Netherlands. Available on http://www.isric.org.

2. Pataki, D. E., et al. Tracing changes in ecosystem function under elevated carbon dioxide conditions. BioScience 53, 805-818 (2003).

3. Su YZ, Zhao HL. Advances in researches on soil organic carbon storages, affecting factors and its environmental effects. Chinese Journal of Desert Research. 2002; 20(3): 220-228. [Google Scholar]

4. Unger PW, Jones OR. Long-term tillage and cropping systems affect bulk density and penetration resistance of soil cropped to dryland wheat and grain sorghum. Soil and Tillage Research.1998; 45: 39-57. [Google Scholar]

5. Emmanuel, R. Estimating the environmental suitability of wall materials: Preliminary results from Sri Lanka. Build. Environ. 2004, 39, 1253-1261. [CrossRef]

6. Gerilla, G.P.; Teknomo, K.; Hokao, K. An evaluation of carbon emission changes in the Japanese housing sector from 1980-1995. J. Asian Archit. Build. Eng. 2005, 4, 509-515. [CrossRef]

7. Chen, T., Burnett, J. \& Chau, C. 2001, 'Analysis of embodied energy use in the residential building of Hong Kong', Energy, 26 (4), 323-40. doi: http://dx.doi.org/10.1016/S0360-5442(01)00006-8

8. Peng, C. Calculation of a building's life cycle carbon emissions based on ecotect. J. Clean. Prod. 2016, 112, 453-465. [CrossRef]

9. Franzluebbers AJ, Stuedemann JA. Bermudagrass management in the southern Piedmont USA: III. Particulate and biologically active soil carbon. Soil Science Society of America Journal. 2003; 67:132-138. [Google Scholar]

10. Alvarez R, Alvarez CR. Soil organic matter pools and their associations with carbon mineralization. Soil Science Society of America Journal. 2000; 64: 184-189. [Google Scholar] 